\title{
Assessment of the Curricular Reform of a Medical Course from the Faculty's Perspective
}

\section{Avaliação da Reforma Curricular de um Curso de Medicina na Perspectiva dos Docentes}

Maria Valéria Pavan ${ }^{I, I \odot}$
Maria Helena Senger
Waldemar Marques

\section{RESUMO}

Em 2006, o curso de Medicina da Faculdade de Ciências Médicas e da Saúde da Pontifícia Universidade Católica de São Paulo (FCMS da PUC-SP) reestruturou inteiramente seu currículo e o projeto pedagógico, e passou a utilizar métodos ativos de ensino-aprendizagem, centrados na Aprendizagem Baseada em Problemas. É comum haver certa resistência de parte dos docentes em relação às mudanças em função das possíveis consequências para a sua prática diária. Entretanto, a participação do docente e seu comprometimento diante de propostas de reformas são fundamentais para que elas de fato ocorram e se renovem continuamente. Neste sentido, este estudo teve como objetivo avaliar a visão do docente do curso de Medicina da FCMS da PUC-SP sobre as mudanças desencadeadas pela reforma curricular e o impacto destas mudanças sobre seu próprio trabalho, sobre a qualidade do curso e do médico formado e as sugestões para aperfeiçoar o currículo, dentro da busca contínua por um profissional bem formado e adequado às necessidades da população e do sistema de saúde. Os dados foram obtidos por meio de um questionário semiestruturado, pré-testado, enviado aos docentes em atividade no curso. A segunda parte do questionário, objeto deste artigo, deveria ser respondida pelos docentes que já estivessem em atividade antes da reforma curricular. Dos 178 docentes, 102 responderam ao questionário, e, destes, 73 $(71,6 \%)$ já exerciam atividades no curso antes da reforma curricular e responderam à segunda parte do questionário. De maneira geral, os docentes têm uma visão positiva sobre as mudanças desencadeadas pela reforma, com ênfase no papel ativo do aluno no processo de ensino-aprendizagem e no crescimento proporcionado ao professor, gerado pelo modelo pedagógico escolhido. Também consideram que houve melhora na qualidade do curso e do médico formado. Embora bem avaliada, a mudança para um modelo interdisciplinar e as deficiências da estrutura física e dos equipamentos disponibilizados para o curso dificultam o trabalho do professor. A dificuldade na avaliação do aluno e a falta de um plano de capacitação permanente do docente aparecem como os principais problemas a serem enfrentados na busca do aperfeiçoamento do curso.

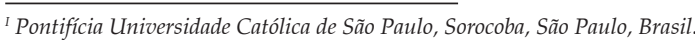

"Universidade de Sorocaba, Sorocoba, São Paulo, Brasil. 


\section{KEY-WORDS}

- Medical Education.

- Curriculum.

- Problem-Based Learning.

- Faculty.

Recebido em 31/3/19

Aceito em 20/5/19
ABSTRACT

In 2006, the medical course of the Faculty of Medical Sciences and Health of PUC-SP (FCMS of PUC-SP) completely restructured its curriculum and pedagogical project and began to use active teaching/learning methods, centered on problem-based learning. There is often some resistance on the part of the teachers in relation to the changes, depending on the consequences for their daily practice. However, the participation of the teachers and their commitment to reform proposals are fundamental for them to occur and to be continually renewed. In this sense, this study had as objective to evaluate the teachers' view of the FCMS of the PUC-SP medical course on the changes triggered by the curricular reform; the impact of these changes on their own work, on the quality of the course and on the graduate doctor and, the suggestions to improve the curriculum, as part of the ongoing goal to produce well-trained professionals adapted to the needs of the population and to the health care system. The data were obtained through a pre-tested semi-structured questionnaire, sent to the teachers working on the medical course. The second part of the questionnaire, object of this article, was to be answered only by the teachers who were already working before the curricular reform. Of the 178 teachers, 102 answered the questionnaire and, of these, $73(71.6 \%)$ had already worked on the course before the curricular reform and answered the second part of the questionnaire. In general, the teachers have a positive view of the changes triggered by the reform, with emphasis on the active role of the student in the teaching/learning process and the growth provided to the teacher, induced by the pedagogical model chosen. They also consider that there has been an improvement in the quality of the course and the graduate doctor. Although well evaluated, the change to an interdisciplinary model and the deficiencies of the physical structure and equipment made available for the course complicate the work of the teacher. The difficulty in evaluating the student and the lack of a permanent teacher development plan appear as the main problems to be faced in the search for improving the course.

\section{INTRODUCTION}

In recent decades, the most diverse institutions involved in medical education have debated the changes necessary to update the teaching model to the new student profile and to health professional training that meets the current requirements of the population and the health system, as guided by the National Curriculum Directives for the Medical Degree Course (DCN - Diretrizes Curriculares Nacionais) ${ }^{1,2}$. Among the changes, those relating to the pedagogical model have been much discussed and introduced in many medical schools, transitioning from the traditional teaching model, centered on the teacher, based on the Flexner Report ${ }^{3}$, with basic and clinical (predominantly hospital) cycles, to a structured model based on the use of active teaching/learning methodologies, centered on the student, and also directed to primary health care ${ }^{1,2}$. Among the active methodologies, Problem-Based Learning (PBL) has been used and compared to the traditional medical education model ${ }^{4-10}$.

In this context, in 2006, the Medical Course of the Faculty of Medical Sciences and Health of the Pontifical Catholic
University of São Paulo (FCMS of PUC-SP), Sorocaba campus, which had followed the traditional medical education model since the 1970s, completely reformulated its curriculum and its pedagogical project to use active teaching/learning strategies centered on PBL. The course was organized in axes, involving horizontal and vertical thematic modules, with complementary learning objectives. A module does not correspond to a subject, as in traditional curricula, but includes content from a variety of areas, favoring an interdisciplinary approach ${ }^{11}$.

The changes in the methodology required not only the teaching concept to be updated, but also the physical structure, installations, equipment and administrative structure, in which the coordination and collegiate bodies for the course perform a regulatory role for delivering the curricular activities and the change process. The practical space was also expanded, which required liaison between the university and the municipal health service, with students being placed in primary health care from the first year of the course, bringing the students closer to the reality of the population in the broadest sense $\mathrm{e}^{11,12}$. 
Many difficulties are faced when implementing and maintaining a pedagogical project such as that proposed for the course in question. Among these, it is common for there to be certain resistance from the teachers with regard to the changes due to the possible impact on their daily activities. However, the participation of the teachers and their attitude towards the proposed reforms are critical for these to actually take place and to be continuously renewed in the quest to make any required adjustments , $^{73-15}$.

Accordingly, the objective of this study was to evaluate the views of the teachers of the Medical Course of FCMS of PUC-SP on the changes resulting from the curricular reform of 2006, the impact of these changes on their own work, on the quality of the course and on the graduate doctor and their suggestions for improving the curriculum, within the ongoing goal to produce well-trained professionals, capable of meeting the requirements of the population and the health system.

\section{MATERIAL AND METHODS}

This study forms part of a doctoral thesis, a collaboration between the post-graduate degree course in Higher Education of the Sorocaba University (Uniso) and the Medical Course of FCMS of PUC-SP, and was approved by the Ethics in Research Committee of the institution (CAAE: 20027213.8.0000.5500) and authorized by the course coordinators and directors of FCMS of PUC-SP

It is exploratory, descriptive, transversal research, with a quantitative and qualitative approach. A questionnaire, pre-tested and organized in two parts, was sent to 178 teachers working on the Medical course, to be answered online, using the Google Drive system, by those who wished to participate in the research. The second part of the questionnaire, the object of this article, was to be answered by the teachers who had already been working before the curricular reform. It has 11 closed questions, on a bipolar Likert scale, with five response options and ends with an open question, "What are your opinions of the curricular reform implemented since 2006?", in an attempt to obtain information in addition to that present in the closed questionnaire and to identify possible explanations for the responses given to the closed questions. Of the 178 teachers, 102 answered the questionnaire, and, of these, 73 (71.6\%) had worked on the course before the curricular reform and answered the second part of the questionnaire.

A descriptive analysis of the results for the closed questions in the questionnaire was performed. The internal consistency of the responses on the Likert scale was evaluated using the correlation coefficient (r), which relates the answer to each question to the other answers from the same participant, cre- ating an " $\mathrm{r}$ " value that can vary from zero to one, being considered consistent when greater than $0.15^{16}$. All responses had $r>0.70$, guaranteeing their internal consistency. To evaluate the reliability of the set of questionnaires on the Likert scale, Cronbach's Alpha was applied, resulting in the value 0.92, showing it has high reliability ${ }^{17}$.

The responses to the open question in the questionnaire were grouped by similar theme, aiming to identify the general opinion of the teachers in relation to the curricular reform and their opinions, suggestions and criticisms about the changes introduced, in an attempt to identify positive and negative factors in relation to the reform ${ }^{18}$.

After analyzing the data obtained in the questionnaire, indepth interviews were conducted with six teachers, with selection criteria: being a teacher on the Medical course, having weekly teaching hours of at least 20 hours and having started the teaching activity before the curricular reform. It was an aim to interview teachers who worked in the different years of the course. Two interviewees worked only in the first three years of the course, one in the final year of the course and three throughout the whole course. The number of interviewees was determined on the basis of the analysis of the interviews and closed when it was found their content was saturated. The transcribed material, approved by the interviewees, was read and re-read to understand the most significant content and to categorize it. ${ }^{19,20}$.

The questions covered in the interviews emerged from the analysis of the responses obtained in the questionnaire, including the teacher's general view of the curricular reform; the impact of the reform on the work of the teacher, on the quality of the course, and on the quality of the graduate doctor; the difficulties in evaluating the student; and the view of the interviewees on the continuous training of the teachers. Reading the interviews enabled new analysis categories to be created: the view of the teachers of the evolution of the course and suggestions for correcting its direction. Extracts from the interviews are given in the results, with the teachers interviewed identified by the numbers (E1) to (E6).

\section{RESULTS AND DISCUSSION}

The structuring of curricular reform in any educational institution is not a simple task, and the challenges appear when changing the concepts that guide it and the daily activities. In this case, the traditional medical education model was changed to problem-solving education, based on the conversational relationship between the educator and the educated in building knowledge, based on having had significant prior experience $^{11}$. 


\section{General view of the teachers}

When questioned objectively on how much they liked the changes in the teaching activities arising from the curricular reform of the Medical course of FCMS-PUC-SP, $42.5 \%$ of the teachers said they liked them, and 34.2\% liked them a lot, given a total positive evaluation of $76.7 \%$. Only $9.5 \%$ answered that they "did not like" them and none responded that they "did not like them at all". Although satisfaction is not the only component of motivation, it certainly contributes greatly to the teachers having a positive view of the changes arising from the reform, which can be considered as a factor in favor of the process.

In considering the open question at the end of the questionnaire, 59 of the 72 teachers were in favor of the reform and the proposed pedagogical model.

\author{
It was necessary and urgent. \\ The curricular reform brought important changes (for the \\ better) in the teaching/learning methodology.
}

\section{The PBL improved the medical training of our students.}

The same was found in the analysis of the interviewees, in which they confirmed the positive view of the reform and the proposed teaching/learning model.

I view the reform that happened here at the faculty as something very positive. (E1)

I evaluate it as positive. [...] I think it really was time for change, and I think it had to be to this method. (E6)

As Almedia et al. ${ }^{21}$ identified in the analysis of teachers' perception regarding the management of medical schools that use active methodologies, it is very important that the managers stimulate and maintain this affirmative environment in relation to the proposed changes, so that they transform into a cycle of continuous renewal of the course.

\section{The work of the teacher}

As can be seen in Table 1, when asked about the influence of the curricular reform on their work, $52.1 \%$ of the teachers answered it had "improved" and 6.8\% answered "improved greatly". In relation to the teaching strategies, $47.9 \%$ of the participants responded that the change to active methodologies improved the work of a teacher and $15.1 \%$ that it was greatly improved. For the two questions, 13.7\% indicated that there had been a deterioration in the work and none indicated it had deteriorated greatly. When questioned on whether the change in the format of the course - previously organized by subjects, to a model with thematic axes and interdisciplinary modules - had impacted on their work as a teacher, $41.1 \%$ indicated it had "improved", 12.3\% "improved greatly" and $15.1 \%$ that it had deteriorated. For $31.5 \%$ of the teachers it had, "neither improved/nor deteriorated".

In a study conducted by Teófilo et al. ${ }^{7}$, organizing a Medical course by modules also appears as a complication for consolidating the curricular reform proposed by the Institution under study. These complications appear in the power relationships between the subjects, knowledge area and management levels. If, on one hand, the curricular model based on thematic axes and modules can be more stimulating, creative and challenging for the teachers, on the other, it requires leaving the comfort of the structure of subjects, where there is familiarity with the themes and the nature of the work. The interdisciplinary model presupposes that the teachers from different areas inter-relate, seeking interfaces with specific knowledge and the desirable exchange and complementarity of know-how, requiring inter-personnel negotiations to be

\section{TABLE 1}

Opinion on the changes to the teaching work of the 73 teachers that experienced the curricular reform and the change to the pedagogical project for the Medical course of the Faculty of Medical Sciences and Health of PUC-SP, Sorocaba, SP

\begin{tabular}{|c|c|c|c|c|c|}
\hline Questions & $\begin{array}{l}\text { Greatly } \\
\text { improved } \\
(\%)\end{array}$ & $\begin{array}{c}\text { Improved } \\
(\%)\end{array}$ & $\begin{array}{l}\text { Neither improved } \\
\text { nor deteriorated } \\
(\%)\end{array}$ & $\begin{array}{c}\text { Deteriorated } \\
(\%)\end{array}$ & $\begin{array}{l}\text { Deteriorated } \\
\text { greatly } \\
(\%)\end{array}$ \\
\hline $\begin{array}{l}\text { How much has the curricular reform } \\
\text { changed your work as a teacher? }\end{array}$ & 6.8 & 52.1 & 27.4 & 13.7 & 0.0 \\
\hline $\begin{array}{l}\text { How much has the change to active } \\
\text { methodologies changed your work } \\
\text { as a teacher? }\end{array}$ & 15.1 & 47.9 & 23.3 & 13.7 & 0.0 \\
\hline
\end{tabular}

\begin{tabular}{c|l}
\hline 138 & REVISTA BRASILEIRA DE EDUCAÇÃO MÉDICA \\
\hline $3(1$ Supl. 1): 135 - $145 ; 2019$
\end{tabular}


established, with great investment in time, as demonstrated by Batista and Almeida ${ }^{13}$ in analysis of teachers' perceptions of PBL. This requires work and is demanding on the teachers, and, for these not to become demotivating factors, there needs to be recognition and recompense $\mathrm{e}^{7,13}$.

The comments made by the teachers in response to the open question in the questionnaire reinforce the data obtained in the closed questions. There are indications that the changes took place due to necessity and the motivation to review the teaching method.

The curricular reform produced a new willingness on the part of the teachers.

The impact of a curriculum with active learning methodologies on teaching practice appears in the need to train the teachers on new teaching practices, on performing interdisciplinary work and on capacity building for formative evaluations.

However, difficulties to be faced in daily activities also appear, related to the model that demands integration.

I consider there is need to [...] have greater integration between the activities, but we have evolved greatly since the start of the current curriculum.

It has complicated the preparation of my work, as it has compromised the workload hours and the distribution in the curriculum matrix.

The interviewees indicate a new pathway that could be opened for the teacher's work and show that the new proposal has had an impact on their activities, with virtuous changes in the teaching/learning process in the medical area, favoring the teachers development, with gains in learning and behavioral change.

I think it has made my work more difficult. [...] the curriculum today requires much more commitment from the teacher, but there is also the positive aspect of the teacher also growing. [...] in recent years [...] I have grown greatly as an educator. (E1)

It takes much more work! In the other model, I always gave the same lessons. Not now. [...], but it is good, it motivates me! I feel more up-to-date! It is rewarding! (E5).

According to the evaluation by Kirkpatrick ${ }^{22}$, commonly used for educational training processes, we could classi- fy these responses as being level 1 (positive satisfaction response), level 2 (learning) and level 3 (change of behavior in the work environment).

The data suggest an aspect of great significance in the change process affecting the teachers, that is, they indicate the end of traditional teaching, which is fed from a subject matrix in which know-how is centralized in the knowledge of the teacher.

Lampert $^{23}$ offers us a comparison between traditional teaching and the new integrated educational practices based on curricular directives, valuing the advantages of the latter in the aspects of the work and development of the teachers, of the pedagogical activities and their scenarios. The traditional teaching activity may appear to be a secure and comfortable pathway, but this apparent security can transmute into bureaucratic behavior to the detriment of research and creativity, inherent to the teaching activity, as suggested by Costa et al. ${ }^{24}$ in research on the good medical teacher.

\section{Participation of the student in the teaching process}

The positive effect of the reform on the involvement of the student in the teaching process was present among the opinions given by the teachers at the end of the questionnaire, cited 15 times.

The aspect that I consider most important is that the students are more active, taking the initiative in their activities, questioning the teacher more and are more thoughtful.

In the interviews, the active participation of the students appears as a fundamental aspect for the positive evaluation for the changes arising from the curricular reform.

The main impact I have noticed is the interest of the student [...] I have no question [...] that this was positive. It brings a more interested student, debating the subject [...] The student is more involved, more pro-active. (E2)

Another teacher put it like this:

[...] A positive aspect, without question, is the self-learning. [...] It has improved greatly! (E3)

This change in the attitude of the student is the premise on which the use of active methodologies is based, that is, learning centered on the student and the development of the ability to learn how to learn, as supported by Santos ${ }^{25}$, when PBL was first being implemented in Brazil. National ${ }^{4,6}$ and 
international ${ }^{8,9,10}$ studies show that the search for knowledge, initiative, and leadership skills with personal criticism and limits are among the positive data in using PBL as a teaching methodology.

This proactivity of the student, according to the teachers, helps the integration between the different areas of knowledge that make up the curriculum of the Medical course, forming, in this case, a point of arrival and impacts positively on their behavior with regard to the medical activity.

I see the students initiating the skills from the first year, becoming more involved when they come to the professional part of the course. They have more acceptable medical language and a different attitude, different communication. They are more involved in the clinical cases and seek explanations in the basic subjects for what they find in the clinical cases. (E4)

In the perception of the teachers, the curricular reform achieved the objectives of producing a student with greater autonomy and ability to think, (Kirkpatrick level 3), constituting a strong indicator in the formative process of constructing knowledge ${ }^{22}$.

\section{The course and the graduate doctor}

But what do the teachers think of the quality of the course? Without doubt, this is a central issue, the reason for reforming the Medical course. Notwithstanding the questions raised, it can still be said the it is generally viewed favorably.

The responses (Table 2) to the question in the questionnaire, "how much has the curricular reform improved or deteriorated the quality of the course?" show that for $72.6 \%$ of the teachers the reform improved the quality of the course, while $11 \%$ thought it had deteriorated. Here again there could be a positive effect on the motivation of the teachers, collaborating so that the proposed teaching model is consolidated not through being imposed, but by the continuous integration between satisfaction and the perception of good results.

When questioned on the use of the active methodologies on the quality of the graduate doctors (Table 2), $67.1 \%$ of the teachers stated it had improved, $11 \%$ said it had deteriorated and $21.9 \%$ had not seen a change. The same is found in relation to the question about the interdisciplinary model based on thematic axes: $65.8 \%$ of the teachers said that the quality of the graduate doctors from the institution had improved, $20.5 \%$ said that it had not made a difference and $13.7 \%$ said it had deteriorated.

The analysis of the opinions from the teachers at the end of the questionnaire suggests that, although there was a positive view of the teaching/learning process, the difficulties related to evaluating the knowledge of the student and the impact of the reform appeared to generate uncertainty about the evaluation of the graduate professional. It appears there is a perception that the reform process is incomplete.

I think that the students are much more motivated. However, evaluation instruments that are really effective at evaluating the performance of the student are lacking.

It is not possible to evaluate the impact of the curricular reform on the training of the student, because we do not have specific instruments.

We have a lot of work still to do, with regard to improving medical teaching in our faculty.

\begin{tabular}{|c|c|c|c|c|c|}
\hline \multicolumn{6}{|c|}{$\begin{array}{l}\text { TABLE } 2 \\
\text { Opinion of } 73 \text { teachers who experienced the curricular reform and the change in the pedagogical } \\
\text { project for the Medical course of the Faculty of Medical Sciences and Health of PUC-SP, Sorocaba } \\
\text { (SP) on the changes in the quality of the course and on the graduate professionals }\end{array}$} \\
\hline Questions & $\begin{array}{l}\text { Greatly } \\
\text { improved } \\
(\%)\end{array}$ & $\begin{array}{c}\text { Improved } \\
(\%)\end{array}$ & $\begin{array}{l}\text { Neither improved } \\
\text { nor deteriorated } \\
(\%)\end{array}$ & $\begin{array}{c}\text { Deteriorated } \\
(\%)\end{array}$ & $\begin{array}{l}\text { Deteriorated } \\
\text { greatly } \\
(\%)\end{array}$ \\
\hline $\begin{array}{l}\text { How much has the curricular reform } \\
\text { changed the quality of the course? }\end{array}$ & 12.3 & 60.3 & 16.4 & 11.0 & 0.0 \\
\hline $\begin{array}{l}\text { How much has the change to active } \\
\text { methodologies changed the quality } \\
\text { of the graduate doctors? }\end{array}$ & 8.2 & 58.9 & 21.9 & 9.6 & 1.4 \\
\hline $\begin{array}{l}\text { How much has the change to the } \\
\text { interdisciplinary model changed the } \\
\text { quality of the graduate doctors? }\end{array}$ & 5.5 & 60.3 & 20.5 & 13.7 & 0.0 \\
\hline
\end{tabular}


In the interviews, the teachers tend to have a positive evaluation of the changes produced by the reform, although with reservations. These appear to be related to the lack of data on the results, which complicates forming a consistent judgement. However, a positive view of the quality of the graduate professional predominates.

The students coming from the active methodologies are more developed, more willing and have more initiative. [They] have more potential to be autonomous throughout their professional lives. (E1)

Today, looking critically, I think that we train students very well. (E6)

A difficult question, because it is based on guesswork, which makes it complicated. I would say yes, things are different. (E3)

The clarity of the institution in relation to the objectives to be achieved is fundamental for the teachers to be more secure in relation to their activities. This is only possible through a rigorous evaluation of the educational program. It is necessary to share these objectives with all the members of the academic community and maintain a process of continuous evaluation of the different steps in the teaching/learning process so that constant feedback can be provided to the teachers and other members of this community ${ }^{26}$.

\section{Physical installations and availability of equipment}

With regard to the impact of the curricular reform on the quality of the physical installations and the availability of equipment, $72.5 \%$ of the teachers considered there had been improvements in the physical installations and 73.9\% thought there was an improvement in the availability of equipment for the course. However, it was clear that the teachers expected more, as there were negative opinions with regard to the physical structure and equipment in the analysis of the questionnaire and in the data obtained in the interviews.

There is a need for other educational tools [...] to be increased, such as [...] simulation activities.

[I] hoped for a better improvement in the educational resources.

The laboratories are flawed [...] the Basic Health Units [UBS - Unidade Básica de Saúde] are not accepting of the students.
The interviews demonstrate the difficulties generated by the structural deficiencies, which require the teachers to expend more energy, including for daily activities.

I am tired of always having to fight to give the lesson. (E2)

The report from one teacher appears to summarize this view of the current time in terms of the pedagogical project and the structure for its operation

The pedagogical project that we have is an innovative project and meets international standards [...] But this discrepancy with the infrastructure and the organization of the teachers complicates achieving the targets stipulated in the pedagogical plan. (E4)

It appears that the modifications to the physical structure and the equipment necessary for medical practice, under the proposed pedagogical model, have not managed to follow the pace of the implementation of the curriculum, generating concrete difficulties in the daily activities of the teachers.

We had [...] a focus on the curricular structure part, the educational and pedagogical organization of the course [...], but the infrastructure and the preparedness of the teachers were not addressed with the same emphasis. (E4)

In accordance with these data, a study conducted among the medical schools that had support from the Incentive Program for Curriculum Changes (Promed - Programa de Incentivo a Mudanças Curriculares) for their curricular reforms, which included the Medical course of the FCMS of PUC-SP, shows that the failings in the physical structure, the equipment and the human resources appeared among the complaints of the interviewees in eight of the 19 schools that participated in the study ${ }^{14,27}$. These data show the mismatch between the proposed changes and the adjustments necessary for their implementation, probably because these depend on resources not provided by the program.

\section{Comments against the reform}

Although the answers to the closed questions in the questionnaire show a clear positive evaluation, in all there is a small percentage of the teachers that considered there had been a deterioration in the aspects studied. In the analysis of the responses to the open question, at the end of the questionnaire, the comments that indicate dissatisfaction with the curriculum or with the changes arising from the curricular reform address evaluation of 
the students, teacher training, lack of content in the basic areas, lack of integration between the knowledge areas, need to revise the pedagogical project, lack of commitment from the teachers, and need to evaluate the course. Figure 1 shows the absolute number of times that the most frequent complaints appear in the comments to the open question put to the participants.

Figure 1

Absolute frequency with which negative points appeared in the comments from the participating teachers $(n=73)$ in response to the open question in the questionnaire

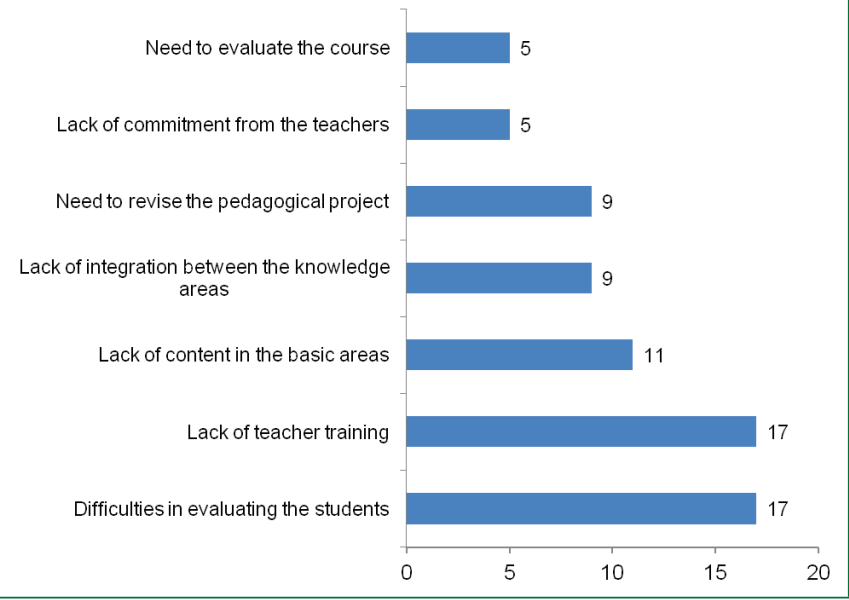

The suggestions and criticisms about the deficiency in the integration between the knowledge areas (nine times) and failures in the content of the basic areas (11 times) appear very consistently among the participants who were against the reform, which shows coherence in the answers. The implementation of a reform, whatever it may be, requires the people involved to adopt the new pedagogical proposals. It is necessary to recognize the factors that ensure the subject concepts continue to be present in the conversation of the teachers working on a course that aims for an interdisciplinary approach in its broadest aspects. This recognition may possibly create an environment for seeking a set of solutions to achieve what everyone desires, here represented by the training of good doctors.

The frequency with which the difficulties in the basic areas were perceived and cited as negative observations on the reform is noteworthy. Seven came from participants who demonstrated they were against the reform, three by teachers who were neutral and only one by a teacher in favor of the reform. One teacher put it as follows:
Although the observations relate to the previous basic subjects, they are made by teachers who work in different years of the course. That is, they do not appear to have been made by teachers of the previous basic subjects, who might have felt devalued in their work given the changes. A study conducted in a medical school in Germany evaluated, by means of the progress test, the acquisition of specific knowledge of the basic sciences and confirmed that, in traditional teaching, there may be superiority in the early semesters, but at the end of the course there was no statistical difference in comparison to teaching using the PBL method, which could justify this perception on the part of the teachers ${ }^{28}$. However, here, this perception may also represent the persistence of a security concept based on the linear transmission of knowledge and on the repetition of learning models throughout the medical training.

The negative evaluations of staff training and evaluating the student

As can be seen in Figure 1, the difficulty in evaluating the student was cited 17 times in the open question in the questionnaire. Notably, with a certain dissatisfaction with what has been happening.

Evaluation instruments that are really effective are lacking, for evaluating the performance of both the student and the teacher.

I believe that the evaluation of the internship student requires greater care: all of the clinics should use the evaluation methods (e.g. Mini-CEX) in the same way.

The reports from the interviews reinforce the difficulty with regard to evaluating the student, showing that, even among those clearly in favor of the curriculum in practice, there is a perceived difficulty encountered in the evaluation.

We are sinning in the matter of evaluation [...] We are far from what is needed in this matter of evaluation, for both the students and the course [...] it is a failure of the curriculum. (E1)

The lack of teacher training was cited 17 times in the open question in the questionnaire (Figure 1). In this aspect, the position of the interviewees is frankly negative.

No, in no way! I am going to look for many things myself.

$(E 2)$ 
Continuous training does not appear to form part of the activities proposed by the institution, from what can be gathered from the statements.

The institution has not worried much about this. I think this is being done by individual commitment and informally by us [teachers]. Helping each other with the difficulties. But there is no institutional concern in this regard. (E4)

In institutions that propose making curricular changes, it is common for teachers to have a certain difficulty in regard to evaluation, as demonstrated by Alves et al. ${ }^{14}$. It is necessary to be clear that the professional development processes are indispensable for the intended changes to be successful and it is important that they are included in the context of the institution and take place in a permanent way ${ }^{13,29,30}$.

The comments on the lack of a consistent teacher development program are perceived most specifically in the evaluation of the learning of the student, where insecurity and difficulty predominate, as in the example of this statement:

Evaluation [...] Ah! I have been lost with this for some time. I find it difficult to evaluate the student. (E2)

The know-how of the medical teachers is constructed commonly not on the basis of having educational-pedagogical training, but on their experiences as students, with their peers and with their own teaching practice, as found by Machado et al. ${ }^{15}$, from the statements from university medical teachers themselves. In this regard, the teachers very clearly presented the difficulties faced with evaluation. Among them, the most important appears to be related to the mismatch between the training of the teacher and the evaluation tools for the proposed pedagogical model, as in the following statement:

I think it is difficult for the teacher to evaluate. Firstly, because we have a serious problem with the changes and the training that we have. (E5).

However, as Costa et al. ${ }^{24}$ also demonstrated, the teachers are aware there is need to fill this gap.

I also see difficulty in conducting the evaluation, both the formative and the summative. We have a lot of work still to do, with regard to improving medical teaching in our faculty.

A series of factors may complicate the improvement in the teaching activity in the health area, among them the devalu- ing of the teaching activity, the lack of teaching professionalization, the devaluing of the teacher training of the medical teacher, the resistance to changes, and individualism ${ }^{21,24}$.

There is also resistance from the teachers to the curricular
reform, even eight years after its implementation. This needs
to be overcome through continuous training.

In the process of implementing the current pedagogical model, the organizers paid attention to teacher training for tutoring the PBL activity, which is very different to previous teaching practices. This initial movement appears to have created a positive environment with regard to the proposed changes.

The initial training and the pedagogical consultancy were fundamental at the time of the reform. (E1)

However, according to the interviewees, there is no clear action plan in relation to the infrastructure, equipment and teacher training. This difficulty in taking decisions may contribute to the insecurity that appears among some of the interviewees.

Planning, managing and motivating the teachers for their activities so that they achieve the desired results requires the development of the leadership implied in this process, with participative management, greater investment in the teachers and preparation and application of continuous training programmes $^{15,21,29}$.

\section{Suggestions for correcting direction}

When changes are made to the curriculum structure and the teaching method, the systematic evaluation of the practices and processes is fundamental to provide feedback for the initiatives by the managers and for correcting direction, which are indispensable for achieving the desired goals. In this regard, the opinions of the teachers, whether in the open questions or in the interviews, are of great importance. The teachers speak frankly of the need for greater integration between the different areas/activities.

I consider it necessary to find solutions for greater integration between the activities, but we have evolved greatly since the start of the current curriculum.

Similar analysis was conducted in the study by Almedia et al.. ${ }^{21}$, which shows the difficulties faced in the integration required to implement a Medical course that had PBL as the central curricular axis. In this study, the interviews stressed the fundamental role of the managers who, in the view of the 
authors, must perform the role of evaluators of the process of implementing the changes, correcting its direction ${ }^{21}$.

The teachers who experienced the previous curriculum report positive changes in student learning and in student work. However, they present a certain despondency and highlight a lack of stimulation, lack of objectives and lack of harmony between the maintaining entity and the academic administration.

What I see in the faculty, which annoys me, is that I am seeing a series of things deteriorate, and I see that we are failing to find a way to resolve these matters. (E2)

I feel that there is a very large mismatch between the [maintainer] and the Dean's Office. [...] a lack of dialogue between the actions of the [maintainer] and the Dean's office, involving the teaching, the teachers and the teaching activity. (E4)

The statements from the teachers indicated ways to enable advances in the direction of more effective changes that would result in teaching and training of the medical professional to a higher standard. It was found, in the following statement, that the teacher saw that the project itself carried mechanisms to guide its direction, and it appears that these mechanisms are not being used to their full potential, but could be a route to correct the direction.

We have some committees, which are fundamental bodies for the development of the current curriculum. One of them is called the Evaluation Committee [...], but it is unclear what its priorities are. [...]. The Teacher Structuring Centre is responsible for monitoring the pedagogical project over time to correct the direction and make modifications to whatever is shown to be inefficient in the project. There are two meetings at most during the academic year [...]. And there is another very important committee, the Teacher Training and Continuous Education Committee [...]. This was structured and organized officially, but [...] the university did not give it the conditions for it [...] to perform its duties. (E4).

Even if at some times they say they are unmotivated, the teachers show they are concerned with the future of the course, making a series of criticisms and indicating possible corrections for the direction. This fact deserves to be valued and explored by the institution.

The data from this study does not enable the responses of indifference presented in the closed questions of the questionnaire to be explored. However, it is worth managers giving them attention, because they may represent a significant per- centage of the teachers who have not accepted the proposed changes, requiring greater effort from the group to maintain direction. Another limitation of the study was to have conducted the evaluation of the educational process only from the perspective of the teachers. Other studies are necessary to evaluate the views of the students, particularly the new students, and the performance of the students in external evaluations.

\section{CONCLUSIONS}

The teachers, in general, recognize that the curricular reform of the Medical course in question brought positive changes to the course as a whole, with the focus on the students, who become protagonists in the new learning situations, as well as for the teachers, who are more stimulated in their daily activities. Although they showed a positive view in relation to the quality of the course and the graduate professional, the teachers appear to lack evidence to give a secure opinion in this regard. In addition, the difficulties with student evaluation show the lack of a permanent training plan for the teachers, which needs a joint effort from the different sectors of the institution.

\section{REFERENCES}

1. Brasil. Ministério da Educação. Conselho Nacional de Educação. Resolução CNE/CES no 4, de 7/11/2001. Institui Diretrizes Curriculares Nacionais do Curso de Graduação em Medicina. Brasília (DF): Ministério da Educação; 2001.

2. Brasil. Ministério da Educação. Conselho Nacional de Educação. Resolução CNE/CES no 3, de 20/06/2014. Institui Diretrizes Curriculares Nacionais do Curso de Graduação em Medicina. Brasília (DF): Ministério da Educação; 2014.

3. Flexner A. Medical Education in the United States and Canada Bulletin Number Four (The Flexner Report). Carnegie Bull. 1910. p. 364.

4. Gomes R, Brino RF, Aquilante AG, Avó LRS. Aprendizagem Baseada em Problemas na formação médica e o currículo tradicional de Medicina: uma revisão bibliográfica. Rev. bras. educ med. 2009; 33(3):433-40.

5. Gomes AP, Rego S. Transformação da educação médica: é possível formar um novo médico a partir de mudanças no método de ensino-aprendizagem? Rev. bras. educ med. 2011; 35(4):557-66.

6. Leon LB, Onofrio FQ. Aprendizagem Baseada em Problemas na Graduação Médica - Uma Revisão da Literatura Atual. Rev. bras. educ med. 2015; 39 (4):614-619.

7. Teofilo TJS, Santos NLP, Baduy RS. Apostas de mudança na educação médica: trajetórias de uma escola de medicina. Interface. 2017; 21(60):177-188. 
8. Qin Y, Wang Y, Floden RE. The Effect of Problem-Based Learning on Improvement of the Medical Educational Environment: A Systematic Review and Meta-Analysis. Med PrincPract. 2016;25(6):525-532.

9. Neville AJ. Problem-Based Learning and Medical Education Forty Years On. Med PrincPract 2009;18(1):1-9.

10. Schauber SK, Hecht M, Nouns ZM, Kuhlmey A, Dettmer S. The role of environmental and individual characteristics in the development of student achievement: a comparison between a traditional and a problem-based-learning curriculum. Adv Health SciEducTheoryPract. 2015;20(4):1033-52.

11. Pontifícia Universidade Católica de São Paulo. Faculdade de Ciências Médicas e da Saúde. Projeto pedagógico do curso de medicina. Sorocaba: PUC-SP/FCMS; 2014.

12. Anjos RMP, Gianini RJ, Minari FC, Luca AHS, Rodrigues MP. "Vivendo o SUS" uma experiência prática no cenário da atenção básica. Rev. bras. educ med. 2010; 34(1):172-83.

13. Almeida EG, Batista NA. Desempenho docente no contexto PBL: essência para aprendizagem e formação médica. Rev. bras. educ med. 2013; 37(2):192-201.

14. Alves CRL, Belisário SA, Lemos JMC, Abreu DMX, D'Ávila LS, Goulart LMHF. Mudanças curriculares: principais dificuldades na Implementação do PROMED. Rev. bras. educ med. 2013; 37(2):157-166.

15. Machado MMBC, Sampaio CA, Macedo SM, Figueiredo MFS, Rodrigues Neto JF, Lopes IG, et al. Reflexões e significados sobre competências docentes no ensino médico. Avaliação. 2017; 22(1):85-104.

16. Moraes SG. Desenvolvimento e avaliação de uma metodologia para o ensino de embriologia humana [tese]. Campinas: Universidade Estadual de Campinas; 2005.

17. Bland JM, Altman DG. Cronbach's alpha (Statistics notes). BMJ 1997:314:572.

18. Gomes R. Análise e interpretação de dados em pesquisa qualitativa. In: Pesquisa social: teoria, método e criatividade. Minayo M, editor. 30th ed. Petrópolis: Vozes; 2011. p. 79-107.

19. Bogdan R, Biklen S. Investigação Qualitativa em Educação: uma introdução à teoria e aos métodos. Porto: Porto Editora, 1991.

20. Taquette SR, Minayo MCS. Ensino-Aprendizagem da Metodologia de Pesquisa Qualitativa em Medicina. Rev. bras. educ med. 2015;39(1):60-7.

21. Almeida MTC, Maia FA, Batista NA. Gestão nas escolas médicas e sustentabilidade dos programas de desenvolvimento docente. Avaliação. 2013;18(2):299-310.
22. Kirkpatrick DL. Evaluating Training Programs: The Four Levels: Easyread Edition, 2009.

23. Lampert JR. Dois séculos de escolas médicas no Brasil e a avaliação do ensino médico no panorama atual e perspectivas. GazMed Bahia. 2008; 78(1):31-7.

24. Costa NMSC, Cardoso CGLV, Costa DC. Concepções sobre o bom professor de medicina. Rev Bras Educ Med. 2012; 36(4):499-505.

25. Santos SR. O aprendizado baseado em problemas (Problem-basedlearning - PBL). Rev. bras. educ med. 1994; 18(3):121-4.

26. Goldie J. AMEE Education Guide no. 29: evaluating educational programmes. MedTeach 2006;28(3):210-24.

27. Brasil. Ministério da Saúde. Ministério da Educação. Secretaria de Políticas de Saúde. Secretaria de Ensino Superior. Organização Pan-Americana de Saúde. Programa de Incentivo a Mudanças Curriculares nos Cursos de Medicina. Brasília: Ministério da Saúde; 2002.

28. Nouns Z, Schauber S, Witt C, Kingreen H, Schüttpelz-Brauns K. Development of knowledge in basic sciences: a comparison of two medical curricula. Med Educ 2012; 46 (12):1206-14.

29. Rego C, Batista SH. Desenvolvimento docente nos cursos de medicina: um campo fecundo. Rev. bras. educ med. 2012; 36 (3):317-324.

30. Steinert Y, Mann K, Centeno A, Dolmans D, Spencer J, Gelula $\mathrm{M}$, et al. A systematic review of faculty development initiatives designed to improve teaching effectiveness in medical education: BEME Guide No. 8. Med Teach. 2006; 28(6):497-526.

\section{CONTRIBUTION OF THE AUTHORS}

Maria Valéria Pavan: participated in all stages of the project. Maria Helena Senger e Waldemar Marques: participated in the design, analysis, result interpretation, and final review of the project.

\section{CONFLICT OF INTEREST}

The authors declare no conflict of interests

\section{CORRESPONDENCE ADDRESS}

Rua Ilda do Amaral Cussiol, 155, Jardim Isaura, Sorocaba, SP, Brasil. CEP: 18047-594.

E-mail: mvpavan@globo.com 